\title{
Breast Cancer Management: Present Scenario
}

\author{
Th. Tomcha Singh
}

\begin{abstract}
Abstrak
Penatalaksanaan kanker payudara mungkin merupakan suatu hal yang amat kontroversial dan telah mengalami perubahan luarbiasa dengan berjalannya waktu. MRI dengan kontras muncul sebagai alat diagnostik pencitraan yang paling efisien. Pendekatan yang mutakhir untuk biopsi kanker payudara yang tidak sesuai untuk pembedahan, ditujukan untuk mendapatkan sampel jaringan yang cukup untuk keperluan diagnostik namun meminimalkan penyebaran dan resiko komplikasi. Penanganan regional yang dilakukan Halstead secara ketat, walaupun berhasil mengendali lokal regional secara bermakna, namun tidak berhasil meningkatkan kesintasan (survival) jangka panjang. Dengan berjalannya waktu, orang telah memahami disposisi sistemik penyakit ini dan pentingnya menggabungkan terapi sistemik bahkan sejak tahap dini dan melengkapi teknik ablatif surgikal. Peranan terapi sistemik primer dalam manajemen kanker payudara dengan cepat muncul sebagai suatu pilihan yang vital. Pada pasien dengan ekspresi berlebih gen HER 2/neu, tambahan 'transtuzumab' pada pengobatan sistemik menghasilkan peningkatan yang jelas pada kesintasan secara keseluruhan. (Med J Indones 2007; 16:55-60)
\end{abstract}

\begin{abstract}
The management of breast cancer is perhaps the most controversial of all and has evolved a sea change over the years. Contrast enhanced MRI imaging is emerging as the most efficient imaging diagnostic tool. Newer approaches for the biopsy of inoperable breast cancer are aimed at obtaining diagnostically adequate tissue samples while minimizing invasiveness and the risk of complications. The regional vigour that Halsted followed rigorously, albeit, achieved significant locoregional control, could not lead to improved long-term survival. With the passage of time, people have understood the systemic nature of the disease and the paramount need to incorporate systemic treatment even in relatively earlier stages and curtain surgical ablative techniques. The role of primary systemic therapy in the management of breast cancer is fast emerging as a vital option. In HER 2/neu gene overexpressed patients, addition of trastuzumab to the systemic treatment is a distinct improvement in overall survival. (Med J Indones 2007; 16:55-60)
\end{abstract}

Keywords: breast cancer, tumour, chemotherapy, radiotherapy, systemic therapy

Breast cancer is by far the most common female cancer worldwide accounting for $21 \%$ of all cancers diagnosed in women. The incidence of the disease vary globally with high rates in North America and Western Europe, intermediate rates in South America and Eastern Europe and low rates in Asia. But the disease is fast picking up in developing countries while it is getting stabilized or slightly down in developed countries and thus the difference in incidence and mortality is getting narrower. The reason of increased incidence in developing countries is because of urbanization while in the later it is because of more adoption of screening programmes and early detection. The focus of this review is to highlight the latest developments in the management of the disease.

Department of Radiotherapy, Regional Institute of Medical Sciences, Imphal-795004, Manipur, India.

\section{DIAGNOSIS}

\section{Newer Trends in Breast Cancer Biopsy:}

Newer approaches for the biopsy of non palpable breast lesions are aimed at obtaining diagnostically adequate tissue samples while minimizing invasiveness and the risk of complications.

\section{Advanced Breast Biopsy Instrumentation System (ABBI):}

It was designed as an alternative to conventional excisional biopsy for the diagnosis of non palpable breast cancers. With 3 dimensional stereotactic localization, an axial wire is guided to the centre of the tumour. The wire is used as a guide to insert a surgical canula that removes a tissue cylinder encompassing the tumour. Tissue cylinders of varying lengths and $5-20 \mathrm{~mm}$ diameters can be removed. This is significantly larger tissue sample than could be removed through core 
biopsy and does not require multiple passes of the needle. The procedure can be carried out under local anaesthesia and on an outdoor basis. ${ }^{1,2}$ Several institutions are testing the $\mathrm{ABBI}$ system with promising results.

\section{Vacuum Assisted Core Biopsy}

This device uses the same general principle as the core needle biopsy but is capable of obtaining upto 10 times as much tissue as a core needle. Two systems currently in use are the Mammotome and the Minimally Invasive Breast Biopsy (MIBB). These devices are positioned in the breast with the aid of stereotactic or ultrasound guidance and uses high speed rotating knives to remove tissue that is removed by vacuum. They have the advantage of being able to obtain additional samples within one area by being turned in a circular motion. The probe may also be used to insert radio-opaque markers at the biopsy site to mark the lesion for further management. Vacuum assisted core sampling devices have proved to be as accurate as surgical biopsy for small non palpable lesions and are particularly useful in the assessment of diffuse calcifications. ${ }^{3}$

\section{Sentinel Lymph Node Biopsy (SLNB)}

It has received much attention as possible alternative to Axillary Lymph Node Dissection (ALND) for the detection of axillary metastasis. If the sentinel lymph is negative, other nodes are presumed to be negative; thus morbidity of ALND could be avoided by voiding the axillary dissection. Sentinel lymph node (SLN) is identified by injecting either a vital dye or a colloidal suspension of radioactivity tagged substance into the periphery of the primary tumour site or intradermal injections into the skin over the tumour or the periareolar lymphatic plexus. ${ }^{4}$ In case of vital dye, SLN is detected during surgery but for the radioactivity, localization can be done before surgery and hence is a preferable practice. By this technique, SLN can be identified in as high as $90 \%$ of the cases.

SLNB is becoming an alternative to level I and II lymph node dissection for staging of patients with operable breast cancer.

\section{Immunohistochemistry Techniques}

Occult micrometastases were defined as tumour deposits not larger than $2 \mathrm{~mm}$ in the axillary lymph nodes (AJCC). Patients who were declared node negative histologically are found to have occult nodal metastases in $10-29 \%$ of the instances when stained with immunohistochemistry techniques. ${ }^{6}$

\section{Molecular Techniques}

A very fine level of resolution in the detection of isolated tumour cells and micrometastases is potentially available with the use of reverse transcriptase-polymerase chain reaction technique (RT-PCR). RT-PCR is theoretically of identifying single cells.

\section{ADVANCES IN BREAST IMAGING}

\section{Digital Breast Tomosynthesis: 3 Dimensional Mammography}

The implementation of screening mammography (MMG) had a dramatic impact in the early detection of breast cancer; however, it is well recognized that conventional MMG cannot detect all breast cancers. In fact, as many as $20 \%$ of early breast cancer that can be missed by MMG. ${ }^{7}$ This limitation becomes more pronounced as tissue density of breast increases. The major factor contributing to the limitations of conventional MMG is the structure overlap that results on a 2 dimensional MMG. Structure overlap can not only obscure images but it can also mimic abnormalities, thus leading to reduction in both sensitivity and specificity of MMG.

Digital breast tomosynthesis is a new 3 dimensional MMG technique which can provide cross sectional imaging study of the breast that virtually eliminates confounding structure overlap, allowing more accurate diagnosis, reduces false positive results and permits precise lesion localization. One of the distinct advantages of tomosynthesis is that it extends the capabilities of conventional MMG, a modality that is affordable, easily available, well studied and well understood. ${ }^{8}$

\section{Breast Magnetic Resonance Imaging}

The potential of breast MRI was recognized early but it is only recently that its diagnostic power has been exploited in a major way. MRI failed to demonstrate any improvement in the diagnosis of breast disease till the advent of a contrast medium known as godalineum in Europe. Investigators found that breast cancer enhances early after a bolus of the contrast. Breast cancer enhances because of increased capillary permeability. It so happens that godalineum complex used as a contrast agent is just the right size to leak from the abnormal breast tumour capillaries to a greater extent than from normal tissue vessels. ${ }^{9,10}$ This 
unique feature is the key to success of this contrast MRI and its availability to detect diseases that cannot be seen by any other method. Even in-situ carcinomas have abnormal capillary permeability. Studies have shown that the negative predictive value of breast MRI approaches $100 \%$. Indeed the real value of breast MRI is its ability to exclude diseases. No other imaging test can presently match this performance. ${ }^{11}$

\section{Positron Emission Tomography (PET)}

The metabolism of tumour cells take place predominantly through glycolysis. Human benign tumours display some increased glycolytic activity but much to a lesser extent as compared to that of malignant tumours. The differential is the basis of breast cancer imaging with PET. The PET tracer is a cyclotronproduced ${ }^{18}$ F-labelled glucose analog, 2- $\left[{ }^{18} \mathrm{~F}\right]$-fluro-2deoxy-d-glucose (FDG). When FDG is taken up by tumour cells and phosphorylated by hexokinase to FDG-6-phosphate, it is not metabolized further and remains trapped in the cells because tumour cells do not contain significant amount of glucose-6-phosphate to reverse the action. The amount of FDG uptake is inversely proportional to the degree of differentiation of the tumour cells. The major limitation of the PET is poor anatomic detail compared to CT or MRI. ${ }^{10}$

\section{SURGERY}

The present trend is to encourage early detection and opt for minimally invasive ablation techniques or breast conservation surgery. When more aggressive surgery is indicated, immediate breast reconstruction is the order of the day.

\section{Minimally Invasive Ablation Technique}

Minimally invasive ablation of primary tumour is possible with a variety of approaches: cryotherapy, heating (e.g. radiofrequency ablation, focused ultrasound, laser interstitial therapy, microwave etc.) or chemical ablation (e.g. ethanol ablation). Techniques that are currently attracting the most attention for the treatment of breast cancer are radiofrequency ablation, laser interstitial therapy and focused ultrasound.

\section{Radiofrequency Ablation (RFA)}

RFA destroys solid tumours through the generation of frictional heat by intracellular ions moving in response to an alternating current. This current flows from an electrode inserted into the tumour to a grounding pad placed externally on the skin. RFA results in cell membrane fluidity, destruction of cytoskeletal proteins and disruption of nuclear structure and DNA replication. ${ }^{12}$ RFA can take care of $\mathrm{T}_{1-2}$ lesions but most effectively for tumours $<3 \mathrm{~cm}$ in diameters.

\section{Laser Interstitial Therapy (LIT)}

LIT destroys tumour cells by means of laser energy delivered through a fibre-optic inserted into the tumour under imaging guidance. Primary tumour lesion upto $2 \mathrm{~cm}$ diameter could be totally ablated with negative margins when $2,500 \mathrm{~J} / \mathrm{mL}$ of tumour was given or the thermal sensors recorded $60^{\circ}$.

\section{Focussed Ultrasound (FU)}

FU for tumour ablation was described by Harari and colleagues and by Hill and Haar. Concentrated FU was used to ablate the tumour cells. At M.D. Anderson Hospital, an ongoing study is using MRI guided focused ultrasound to treat early stage breast cancer with lesion size upto $2 \mathrm{~cm}$ in diameter.

\section{Breast Conservation Therapy (BCT)}

BCT has largely replaced mastectomy as the surgical treatment of choice for early stage breast cancer. Large prospective trials have shown no survival difference between the two surgical approaches, though there is a difference in the pattern of recurrence. Although loco-regional recurrences following mastectomy operations has a grim prognosis, most recurrences following BCT occur at the primary site that can be easily salvaged by additional surgery. Moreover, the psychological and cosmetic advantages of BCT are paramount especially in younger women. However, because the risk of local recurrence in treated breast is lifelong, it is important to reduce that risk through careful patient selection. ${ }^{13}$

\section{Immediate Breast Reconstruction}

Although BCT has been shown to be safe and preferable for many patients of early stage breast cancer, some women still need or prefer to have mastectomies. These women can now receive an immediate breast reconstruction in the same surgery as the mastectomy. Current reconstruction techniques offer excellent cosmetic results and also provide outcomes equivalent to those of standard mastectomy. Albeit reconstructions using silicone gel or saline were initially very popular, the current trend is towards using autologous tissue - 
the most successful of which is the transverse rectus abdominalis muscle (TRAM) flap. In experienced hands, the free TRAM flap has a success rate of $>99 \% .^{14}$

\section{CHEMOTHERAPY}

The understanding of the fact that breast cancer is a systemic disease with as high as $60 \%$ of the overall disease and $80 \%$ in late stages by the time of diagnosis has re-emphasized the importance of systemic treatment that chemotherapy is used more often now than ever in the past. The earlier concept that breast cancer spreads by contiguity is obsolete. It has been proved beyond doubt by a number of multicentric randomized trials that regardless of the extent or radicality of the surgical resection, the probability of cure is inversely proportionate to the initial stage or the extent of the regional nodal involvement. ${ }^{15}$

\section{Primary Systemic Therapy for Operable Breast Cancer}

It may be defined as the first systemic treatment a patient receives after cancer is diagnosed and the term indicates that subsequent therapies are intended. Primary systemic therapy was first introduced in patients with technically inoperable patients. When it was noted that the majority of these patients had a remarkable response with most becoming operable, enthusiasm rose for primary systemic therapy even in operable breast cancer. However, acceptance by mainstream oncology and integration into the curative multidisciplinary management of operable primary breast cancer occurred only in last 15 years. ${ }^{16,17}$

Rationale: Various investigators found that 24 hours after surgical removal of a primary tumour, there is an increase in the leveling index of metastases and a decrease in tumour doubling time, with a remarkable increase in tumour size. Primary radiation therapy also resulted in kinetic changes in distant tumour similar to those that followed surgery. This stimulation of tumour cell growth at the distant site or in remaining primary site is due to release of soluble growth factor. ${ }^{18}$ Therefore, it has been hypothesized that delivering systemic therapy prior to surgery helps minimize micrometastases and prevents cancer growth that might occur after removal of the primary tumour.

Primary systemic therapy can achieve an objective response rate of 50-90\% of which $10-50 \%$ is complete response. Admiringly, systemic therapy before surgery could reduce the size of the primary tumour so that more patients could be treated with lumpectomy. Because complete and near complete responses are common, the use of percutaneousely placed clips into the breast to define primary disease extent under mammographic or ultrasonographic guide in the prechemotherapy stage helps in defining extent of future surgical removal.

This procedure is not without disadvantages though, the most important of which are imprecise clinical and radiological staging and delay in effective local treatment.

\section{Adjuvant Chemo-hormonal Therapy in Node-negative Breast Cancer}

In 1998, Early Breast Cancer Trialists' Collaborative Group (EBCTCG) found that the use of adjuvant chemotherapy leads to an almost equal proportionate risk reduction of relapse and death in node-negative and node-positive breast cancer patients. The last EBCTCG overview presented in September, 2000 entirely confirmed the finding $\mathrm{s}^{[19]}$. These findings support the concept that node-negative breast cancer is not genetically and clinically different from nodepositive patients and that nodal status is a variable prognostic factor only because it defines a time related disease stage and not because it is intrinsically associated to biologically different disease subtypes. In near future, it will be more prudent to tailor chemotherapy treatment decisions according to the following 4 main variables: molecular determinants of response to cytotoxics, pathologic and molecular determinants of disease recurrence and patient characteristics. $^{20}$

Small primary tumours of up to $0.5 \mathrm{~mm}$ diameter that do not involve lymph nodes do not need adjuvant systemic therapy. Tumours of $0.6-10 \mathrm{~mm}$ diameter with adverse factors like nuclear grade, $\mathrm{S}$ phase, lymphovascular invasion and possibly HER 2/neu overexpression do need chemotherapy treatment. It tumour size is $10-20 \mathrm{~mm}$ and if hormone receptor is negative, combination chemotherapy is indicated and if receptor is positive, hormonal therapy \pm combination chemotherapy is indicated. Here some histologies may not require systemic treatment: tubular, colloid, medullary and adenoid cystic. All other patients of lesion $>20 \mathrm{~mm}$ diameter are managed with combination chemotherapy \pm hormonal therapy. ${ }^{21}$ For patients with HER 2/neu overexpression, combination of trastuzumab and chemotherapy gives better response. 


\section{Adjuvant Chemo-hormonal Therapy in Node-positive Breast Cancer}

Any patient of any primary size whose axillary node(s) are positive, do need chemo-hormonal therapy. Premenopausal patient of any primary size with positive axilla and negative hormonal status indicates combination chemotherapy (Taxane containing preferable). If more than 10 nodes are positive, high dose chemotherapy protocol must be used. In the same patient, if hormonal status is positive, combination chemotherapy and hormonal therapy is indicated. Post menopausal patients with negative hormone receptor status of any size indicates combination chemotherapy \pm hormonal therapy. If HER 2/neu gene is overexpressed, trastuzumab must be added in the systemic therapy. The effects of HER 2/neu on tamoxifen resistance is unclear. ${ }^{21}$

\section{RADIOTHERAPY}

NCCN guidelines in Oncology 2006 for breast cancer recommends consideration of radiation to the chest wall and supraclavicular area after chemotherapy for women with 1-3 involved axillary nodes with consideration for inclusion of the epsilateral internal mammary field, though the later had some controversy. Women with 1-3 involved axillary nodes and with primary tumour $>5 \mathrm{~cm}$ diameter or with positive pathological margins must be given postmastectomy and postchemotherapy radiotherapy to chest wall and supraclavicular area with consideration of inclusion of the epsilateral internal mammary field. The later still had some disagreement. Women with 4 or more positive axillary nodes are at substantially increased risk of local recurrence of the disease and hence radiotherapy must definitely be recommended to chest wall and lymph node regions. ${ }^{22}$

Even in axilla negative patients, chest wall irradiation is recommended if primary tumour is $>5 \mathrm{~cm}$ or with positive pathological margins or close (Less than $1 \mathrm{~mm}$ ) pathological margins. Radiotherapy is not recommended for patients with tumour $5 \mathrm{~cm}$ or smaller, negative margins and no positive axillary nodes. ${ }^{22}$

Axillary nodal irradiation may be as effective as axillary lymph node dissection that has an attendant morbidity in $60 \%$ of the patients - lymphoedema, numbness, limitation of arm movement and strength. The EBCTCG performed a meta-analysis of 8 trials comparing axillary nodal dissection to axillary irradiation for the treatment of early breast cancer and found no difference in mortality. ${ }^{23}$

\section{CONCLUSION}

Godalineum enhanced MRI imaging is the single, most effective diagnostic imaging for breast cancer that has overshadowed the otherwise most popular mammography. In the management of breast cancer today, the shift is towards the broad application of systemic therapy using the paradigm of breast cancer as a systemic disease at the time of diagnosis. This is true regardless of the nodal status. The morbidity of axillary nodal dissection can be avoided by substituting with systemic therapy and irradiation of axilla. Sentinel lymph node biopsy has shown extremely promising results in assessing lymph nodal status and thereby as an alternative to axillary lymph node dissection for sampling. While taxane containing regimes are preferable to anthracycline combinations to CMF, inclusion of trastuzumab for HER 2/neu gene overexpression, further enhances survival.

\section{REFERENCES}

1. Portinacasa G, Lucci E, Navarra GG et al. Initial experience with breast biopsy utilizing the Advanced Breast Biopsy Instrumentation (ABBI). J Surg Oncol. 2000; 74: 201-3.

2. Schwartzberg BS, Goates JJ, Keeler SA, Moore JA. Use of Advanced Breast Biopsy Instrumentation while performing stereotactic breast biopsies: review of 150 consecutive biopsies. J Am Coll Surg. 2000; 191: 9-15.

3. Liberman L, LaTrenta LR, Van Zee KJ et al. Stereotactic core biopsy of calcifications highly suggestive of malignancy. Radiology. 1997; 203: 673-7.

4. Kern KA. Sentinel lymph node mapping in breast cancer using subareolar injection of blue dye. J Am Coll Surg. 1999; 189: 539-45.

5. Eleftherios PM. New issues in breast cancer surgical management. In: Gianni B, Gabriel NH, Pinuccia V editors. Textbook of breast cancer. $3^{\text {rd }}$ ed. London: Taylor \& Francis; 2006. p. 115-44.

6. Cote RJ, Peterson HF, Chaiwun B et al. Role of immunohistochemical detection of lymph node metastasis in management of breast cancer. Lancet. 1999; 354: 896-900.

7. Feig SA, Sheber GS, Patchefsky A et al. Analysis of clinically occult and mammographically occult breast tumours. Am J Roentgenol. 1977; 128: 403-8.

8. Elizabeth AR. Breast tomosynthesis: 3 dimentional mammography. In: American Society of Clinical Oncology education book. $40^{\text {th }}$ Annual Meeting. New Orleans: Los Angelis; 2004. p. 45-7.

9. Kelz F, Furman-Haran E, Grobgeld D et al. Clinical testing of high-spacial-resolution parametric contrast-enhanced MR imaging of the breast. AJR. 2002; 179: 1485-92.

10. Jacobs MA, Barker PB, Bluemke DA et al. Benign and malignant breast lesions: diagnosis with multiparametric MR imaging. Radiology. 2003; 229: 225-32. 
11. Steven EH, Sally AH. New imaging techniques. In: Gianni B, Gabriel NH, Pinuccia V editors. Textbook of breast cancer. $3^{\text {rd }}$ ed. London: Taylor \& Francis; 2006.p.115-44.

12. Hamazoe R, Maeta M, Murakami A et al. Heating efficiency of radiofrequency capacitative hyperthermia for treatment of deep-seated tumours in the peritoneal cavity. L Surg Oncol. 1991; 48:176-9.

13. Singletary SE. In: IJCP Group. Oncology special edition. Issue I. India: IJCP; 2003.p. 30-8.

14. Kroll SS, Evans GR, Reece GP et al. Comparison of resource costs between implant-based and TRAM flap breast reconstruction. Plast Reconstr Surg. 1996; 97: 364-72.

15. Nemoto T, Vana J, Bedwani RN. Management and survival of female breast cancer: result of a national survey by the American College of Surgeons. Cancer . 1980; 45: 2917-24.

16. Fisher B, Bryant J, Wolmark $\mathrm{N}$ et al. Effect of preoperative chemotherapy on the outcome of women with operable breast cancer. J Clin Oncol. 1998; 16: 2672-85.

17. Fisher B, Brown A, Mamounas E et al. Effects of preoperative chemotherapy on locoregional disease in women with operable breast cancer: findings from NSABP B18. J Clin Oncol. 1997; 15: 2483-93.

18. Ritter MA. Determination of tumour kinetics: strategies for the delivery of radiotherapy and chemotherapy. Curr Opin Oncol. 1999; 11: 177-82.

19. Early Breast Cancer Trialists' Collaborative Group. Polychemotherapy for early breast cancer: an overview of the randomized trials. Lancet. 1998; 352: 930-42.

20. Angelo DL, Laura B, Marco RT, Luigi C. Use of chemotherapy in patients with node negative breast cancer. In: ASCO 2004 education book. $40^{\text {th }}$ Annual Meeting. Los Angeles; June 5-8, 2004: 36-42.

21. Karin G, Richard T. Chemohormonal management of nonmetastatic breast cancer. Oncology special edition. Issue I. India: IJCP; 2003.p. 28-47.

22. National Comprehensive Cancer Network. Clinical practice guidelines in oncology on breast cancer.2006; V2: MS127.

23. Early Breast Cancer Trialists' Collaborative Group. Effects of radiotherapy and surgery in early breast cancer. N Eng J Med. 1995; 333: 1444-55. 